\title{
Soğuk İklimin İş Kazalarının Oluşumuna Etkisi: Doğu Anadolu Bölgesi'nde Bir Fabrika Örneği
}

\author{
Major The Effect of Cold Climate on Occupational Accidents: A Factory Example in \\ the Eastern Anatolia Region
}

\author{
Elif SARAÇ (D) , Ceylan YOZGATLIGiL iD , Deniz ODABAŞ
}

\begin{abstract}
ÖZET
İş sağlığı ve güvenliği konuları kapsamında sıcaklıkla ilgili olaylar, tüm dünyada kaygı oluşturmaya devam etmektedir. Uzun süre sıcak ya da soğuğa maruziyetle çalışanlarda dikkat ve konsantrasyon bozuklukları, ağır fiziksel işlerde zorlanma, yorgunluk, bitkinlik, vücudun asit baz dengesinde değişimlere bağlı kan dolaşımının etkilenmesi ve ayrıca bunlara bağlı düşmeler işe uyumun azalması hem medikal tedavi gerektiren hastalıklara hem de uzuv kayıplarına varabilen yaralanmalara neden olabilmektedir. Fakat bu konuda yapılan çalışmalarda iş kazalarının kesin ve birincil etmeni olarak soğuk ya da sıcak iklim doğrudan hedef gösterilemeyebilir. Bu korelasyonel/ekolojik araştırmada; Türkiye'de en soğuk iklime sahip illerinden biri olan Erzurum'da araç bakım onarımı ile uğraşan bir fabrikada son 6 yıla ait iş kazası verileri incelenerek konunun önemine vurgu yapılmaya çalıșılmıștır. İș kazalarının yoğunlukla soğuk geçen aylarda gerçekleştiği, Ortalama ve Medyan (ortanca) iş kazası sayıları incelendiğinde ise 6 yıl içerisinde toplam 40 iş kazasının olduğu görülmüștür. Bu fabrika özelinde az sayıda iş kazası olması nedeniyle istatistiksel anlamlı bir ilişki tespit edilmemiștir. Bununla birlikte Erzurum ilinde soğuk havanın Ekim ayında başlayarak Nisan ayına kadar yoğunlukla hissedildiği göz önüne alındığında bu dağılım soğuk iklimin iș kazalarına etkisi olduğu yönünde bir bulgu olarak kabul edilebilir. Soğuk hava koşullarının hâkim olduğu Erzurum ilinde tüm işkollarını içerecek şekilde serinin genişletilmesi ile iklimin iş kazası ve yaralanmalarına etkisinin ayrıntılı incelenmesinin iş sağlığı ve güvenliği uygulamalarına katkı sağlayacağı sonucuna varılmıștır.

Anahtar Kelimeler: Araç bakım onarım sektörü, Ekolojik/korelasyonel çalışma, İş kazası, Soğuk iklim
\end{abstract}

\section{ABSTRACT}

Within the scope of occupational health and safety issues, incidents related to temperature continue to cause concern all over the world. Attention and concentration disorders, strain in heavy physical work, fatigue, exhaustion, effects on blood circulation due to changes in the acid-base balance of the body, and decrease in work compliance due to these, can cause both diseases that require medical treatment and injuries that can lead to loss of limbs. may cause. However, in studies on this subject, cold or hot climate may not be directly targeted as the definitive and primary factor of occupational accidents. In this correlational/ecological research; In Erzurum, one of the provinces with the coldest climate in Turkey, the work accident data of the last 6 years in a factory dealing with vehicle maintenance and repair has been examined and the importance of the subject has been tried to be emphasized. When the average and median (median) work accident numbers are examined, it has been seen that there were a total of 40 work accidents in 6 years. A statistically significant relationship was not determined due to the small number of occupational accidents in this factory. However, considering that cold weather is felt intensely from October to April in Erzurum, this distribution can be considered as a finding that cold climate has an effect on occupational accidents. It has been concluded that expanding the series to include all business lines in Erzurum, where cold weather conditions prevail, and a detailed examination of the effect of climate on occupational accidents and injuries will contribute to occupational health and safety practices.

Keywords: Vehicle maintenance and repair sector, Ecological/correlational work, Occupational accident, Cold climate

Elif SARAÇ I sarac.elf@gmail.com

Atatürk Üniversitesi, Sağlık Bilimleri Enstitüsü, Halk Sağlığı Hemşireliği ABD, Erzurum, Türkiye

Ataturk University, Public Health Nursing Departmen, Erzurum, Turkey.

Ceylan YOzGATLIGIL | ceylan@meta.edu.tr

ODTÜ, Fen Edebiyat Fakültesi, İstatistik Bölümü, Ankara, Türkiye

Middle East Tecnical University, Faculty of Science And Literature, Ankara, Turkey.

Deniz ODABAŞ I adaegedeniz@gmail.com

Ankara Üniversitesi Tıp Fakültesi, Halk Sağlığı ABD, Ankara, Türkiye

Ankara University, Medical Faculty, Public Helth Department, Ankara,Turkey. 


\section{GIIRIŞ}

Çalışma ortamındaki termal riskler direk ya da dolaylı olarak iş kazası sebebi olabilmektedir. Bu konuda yapılan araştırmalar, kazaların meydana gelmesinde pek çok faktörün etkisinden bahsetmektedir. Olumsuz çalışma koşulları, yetersiz iş deneyimleri, düşük eğitim seviyeleri ve işe oryantasyon eksiklikleri, dikkatsizlik ve acelecilik gibi bireysel faktörler ile uygun olmayan ssıtma, aydınlatma, gürültü gibi çevresel etkiler işe bağlı kaza ve yaralanmaların oluşumunda etkili olan faktörlerdendir[1]. Genel olarak değerlendirildiğinde; fiziksel, kimyasal, mekanik ve ergonomik etmenler iş kazası ve yaralanmalarında etkilidir denilebilir [2].

Uluslararası Çalışma Örgütüne (ILO) göre, dünyada her gün yaklaşık iş kazaları nedeniyle 1000 kişinin, işle ilgili meslek hastalıkları nedeniyle 6 bin 500 kişinin yaşamını kaybettiği tahmin edilmektedir. Her yıl ise yaklaşık 350 bin kişinin iş kazası, 2 milyon kişinin ise meslek hastalıklarından yaşamını yitirdiği bilinmektedir. Bu verilere göre ölüm sayılarında artış mevcuttur. Örneğin 2014 yılında iş kazaları veya meslek hastalıklarına bağlı olarak 2 milyon 33 bin, 2017 yılında 2 milyon 78 bin çalışanın hayatını kaybettiği bilinmektedir[3]. Buna göre iş kazası veya meslek hastalıklarından dolayı ölen çalışanların sayısının sadece üç yıl içinde 45 bin arttığını göstermektedir. Ayrıca her yıl 374 milyon iş kazası meydana gelmekte, bu da bir günde 1 milyondan fazla çalışanın iş kazasına maruz kaldığı anlamını taşımaktadır. Sosyal Güvenlik Kurumu (SGK,2019) istatistiklerine göre; 2019 yllında iş kazası sonucu ölen sigortalı iş̧i (5510 Md. 4-1/a kapsamı) sayısı 1147 kişidir[ $[4,5]$ (Tablo 1$)$.

2017 Yllı İş Kazası sonucu ölen işçilerin İşkollarına Göre Dağılımı incelendiğinde; ilk sırada 587 kişi ile inşaat işkolu bulunmaktadır. İnşaat işkolunu 233 kişi ile taşımacı-
Tablo 1: Ölümlü İș kazalarının Yıllara Göre Dağılımı

\begin{tabular}{lc}
\hline Yıllar & Ölüm Sayısı \\
\hline 2011 & 1700 \\
2012 & 744 \\
2013 & 1360 \\
2014 & 1626 \\
2015 & 1252 \\
2016 & 1405 \\
2017 & 1633 \\
2018 & 1541 \\
2019 & 1147 \\
\hline
\end{tabular}

lık işkolu izlemektedir. Konuya ilişkin ayrıntılı bilgiler Tablo 2'de sunulmuştur.

Tablo 2: 2018 Yılı İş Kazası Sonucu Ölen İşçilerin (4-1/ a) İsskollarına Göre Dağılımı

\begin{tabular}{|c|c|c|}
\hline S.N. & İşkolu & $\begin{array}{l}\text { İş Kazası Sonu- } \\
\text { cu Ölümler }\end{array}$ \\
\hline 1 & İnşaat & 587 \\
\hline 2 & Taşımacılık & 233 \\
\hline 3 & Ticaret, Büro, Eğitim ve Güzel Sanatlar & 162 \\
\hline 3 & Metal & 124 \\
\hline 4 & Madencilik ve Taş ocakları & 86 \\
\hline 5 & Genel İşler & 69 \\
\hline 6 & Çimento, Toprak ve Cam & 58 \\
\hline 7 & Konaklama ve Eğlence İşleri & 47 \\
\hline 8 & Gıda Sanayi & 41 \\
\hline 9 & $\begin{array}{l}\text { Gemi Yapımı ve Deniz Taşımacılığı, Ardi- } \\
\text { ye } 16 \text { ve Antrepoculuk }\end{array}$ & 33 \\
\hline 10 & Dokuma, Hazır Giyim ve Deri & 32 \\
\hline 11 & Avcılık, balıkçılık, tarım ve ormancılık & 31 \\
\hline 12 & Enerji & 30 \\
\hline 13 & Petrol, Kimya, Lastik, Plastik ve İlaç & 28 \\
\hline 14 & Ağaç ve Kâğıt & 27 \\
\hline 15 & Savunma ve Güvenlik & 21 \\
\hline 16 & Sağlık ve Sosyal Hizmetler & 12 \\
\hline 17 & Basın, Yayın ve Gazetecilik & 4 \\
\hline 18 & İletişim & 3 \\
\hline 19 & Banka, Finans ve Sigorta & 2 \\
\hline 20 & İşkolu tespit edilemeyenler & 3 \\
\hline \multicolumn{2}{|c|}{ Toplam } & 1633 \\
\hline
\end{tabular}


Ayrıca Tablo 3'te iş kazalarının 2017 ve 2019 yılları arasında en çok yaşandığı sektörler sunulmuştur.

Tablo 3: Ölümlü İş Kazalarının En Çok Yaşandığı Sektörler ve İş Kazası Sayılarının Yıllara Göre Dağılımı

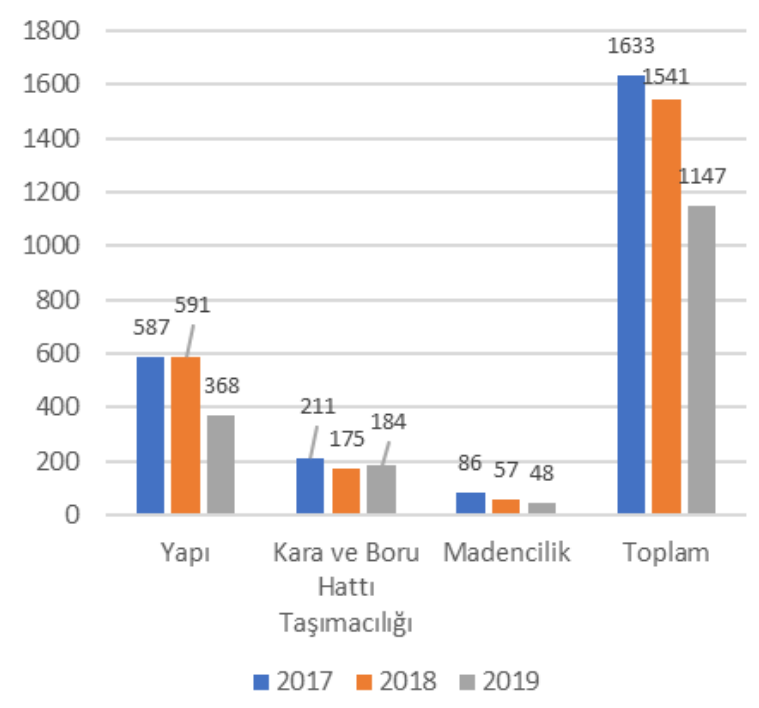

Son yıllarda ülkemizde iş sağlığı ve güvenliği çalışmalarının etkililiğinin artması ile iş kazalarının oranı düşmekte buna karşın gelişmiş ülkelerle kıyaslandığında bu düşüş yeterli olmamaktadır. Çalışılan işkolu ve bölüme göre risk ve tehlikeler farklılık gösterir. Örneğin, inşaat işkolunda dış hava koşullarının olumsuzlukları, ağır ekipman, aşırı gürültü ve yüksekte çalışma riskleri iş kazası oluşturabilecek etmenler iken[6] hastanelerin acil servislerine yapılan başvurularda kesik, sıyrık, delici kesici yaralanmalarının en fazla metal, makina ve inşaat işkolunda görülen iş kazalarına bağlı olduğu belirlenmiştir[7-8]. Tekstil sektöründe çalışanların, düşük güvenlik kültürü ve eğitime sahip olduğu ve yüksek çalışan sirkülasyonu içerdiği görülmüştür[9]. Ayrıca çoğunun 15-44 yaş genç erkekler olduğu, el ve parmaklarda kesilme, laserasyon ve ampütasyona varan sorunlar yaşadığı görülmektedir[10].

İş kazası ve yaralanmaların nedeni olarak çevresel koşulların etkisini de göz ardı etmemek gerekir. Kuzeydoğu İtalya'da en yüksek iş kazası riskinin günlük sıcaklıkların en yüksek olduğu saatlerde gerçekleştiği belirlenmiştir[11]. Nedenleri ise, sıcak havada uygun kişisel koruyucu donanımların kullanılmaması, personelin sıcak iklim koşullarında çalışmaya ilişkin bilgi eksiklikleri ve dehidratasyona bağlı oryantasyon ve uyum bozuklukları olarak belirtilmiştir.

Sıcak iklim gibi soğuk iklimin de iş kazası ve yaralanmalarına etkisi bulunmaktadır. Yaralanmaların çoğu hipotermi ile ilişkilidir. Soğuk havaya uzun süre maruz kalan bireylerde kardiovasküler ve kas iskelet sistemi hastalıklarından, serebrovasküler ve dermatolojik hastalıklara kadar varabilen sorunlar görülmektedir[12]. Özellikle ileri yaşta, kronik hastalığı olan ve uzun süreli medikal tedavi alan bireylerde risk daha fazladır.

$\mathrm{Bu}$ ekolojik/korelasyonel çalışmada; soğuk iklime sahip bir ilimizde araç bakım ve onarımı ile uğraşan bir işyerinde iş kazalarının aylara göre dağılımı incelenmiş, mevsimsel özellikleri belirlenmiş ve soğuk kış aylarında olan yığılım özelinde iş kazalarının soğuk çalışma ortamı ile ilişkisine ait alan yazın gözden geçirilerek sunulmuştur.

\section{II. ÇALIŞMANIN SUNUMU}

Türkiye'de en soğuk iklime sahip illerinden biri olan Erzurum'da araç bakım onarımı ile uğraşan bir fabrikada son 6 yıla ait iş kazası verileri işyerine ait kayıtlardan incelendi. İş kazalarının yoğunlukla soğuk geçen aylarda gerçekleştiği belirlendi. Çalışmanın yapıldığı il olan Erzurum ve iklimi hakkında bilgi vermek gerekirse; Erzurum Anadolu Bölgesi’nin kuzeydoğu kesiminde bulunan, 25.066 km2’lik alanıyla bu bölgenin en büyük, Türkiye'nin ise 4 . büyük ilidir. İlin deniz seviyesinden yüksekliği 1.859 m.'dir. Bir yıl boyunca yaz ve bahar mevsimlerinin yoğunlukla Mayıs, Haziran, Temmuz, Ağustos ve Eylül aylarında yaşandığı, kış mevsiminin ise Ekim, Kasım, Aralık, Ocak, Şubat, Mart ve Nisan aylarında yoğunlukla hissedildiği bir 
Tablo 4: Meteoroloji Genel Müdürlüğü İllere Ait Mevsim Normalleri

\begin{tabular}{|c|c|c|c|c|c|c|c|c|c|c|c|c|}
\hline Erzurum & Ocak & Şubat & Mart & Nisan & Mayıs & Haziran & Temmuz & Ağustos & Eylül & Ekim & Kasım & Aralık \\
\hline En Yüksek Sıcaklık & 8.0 & 10.6 & 21.4 & 26.5 & 29.6 & 32.2 & 35.6 & 36.5 & 33.3 & 27.0 & 20.7 & 14.0 \\
\hline En Düşük Sıcaklık & -36.0 & -37.0 & -33.2 & -22.4 & -7.1 & -5.6 & -1.8 & -1.1 & -6.8 & -14.1 & -34.3 & -37.2 \\
\hline
\end{tabular}

Kaynak: Meteoroloji Genel Müdürlüğü, Ölçüm Periyodu (1929- 2018)

ilimizdir. Uzun yıllar meteorolojik parametrelerin ortalama değerlerine bakıldığında; ortalama sıcaklık $5,6^{\circ} \mathrm{C}$, en yüksek sıcaklık $36,5^{\circ} \mathrm{C}$, en düşük sıcaklık ise $-37,2^{\circ} \mathrm{C}$ dir[13]. Meteoroloji Genel Müdürlüğü'nde alınan illere ait mevsim normallerinin dağılımı Tablo 4’te verilmiştir[14]. ğu görülmüştür. İş kazası sayısı dikkate alınarak yapılan incelemede Mart ve Nisan aylarında 7, Ocak, Temmuz ve Ekim aylarında 4'er iş kazası meydana gelmiştir. En fazla iş kazası yaşanan ayların Ocak, Mart, Nisan, Temmuz ve Ekim ayları olduğu görülmektedir.

Tablo 5: İşyerinde 2014-2019 Yılları Arasında Aylara Göre İş Kazası Sayıları

\begin{tabular}{|c|c|c|c|c|c|c|c|c|c|}
\hline \multirow{2}{*}{$\frac{\text { YIl }}{2019}$} & \multicolumn{8}{|c|}{ Aylar (İş Kazası Sayıları) } & \multirow{2}{*}{$\begin{array}{c}\text { Toplam } \\
9\end{array}$} \\
\hline & Ocak & (1) & Şubat & (1) & Mart (2) & Nisan (2) & Temmuz (2) & Ekim (1) & \\
\hline 2018 & Ocak & (2) & Mayıs & (1) & Eylül (1) & Kasım (1) & Aralık (1) & & 6 \\
\hline 2017 & Ocak & (1) & Mart & (1) & Nisan (1) & Mayıs (1) & Temmuz (1) & & 5 \\
\hline 2016 & Nisan & (3) & Mayıs & (1) & Ekim (2) & Kasım (1) & Aralık (1) & & 8 \\
\hline 2015 & Şubat & (1) & Mart & (2) & Nisan (1) & Temmuz (1) & & & 5 \\
\hline 2014 & Mart & (2) & Haziran & (1) & Ağustos (2) & Eylül (1) & Ekim (1) & & 7 \\
\hline \multicolumn{9}{|c|}{ Toplam } & 40 \\
\hline
\end{tabular}

Çalışmada anılan mevcut işyeri; uzun ve geniş araçların, iş makinalarının bakım ve onarımlarının yapıldığı kamuya ait bir fabrika olup tehlikeli sınıfta yer almaktadır. İşyerinde yalnız Erzurum iline ait araçların bakım ve onarımlarının değil Ağrı, Kars, Iğdır, Doğubayazıt ve Ardahan vb. çevre il ve ilçelerden getirilen araç ve iş makinalarının bakım ve onarımları da yapılmaktadır.

Mevcut işyerinde 2014-2019 yılları arasında aylara göre iş kazası sayıları verilmiştir. Tablo 5 incelendiğinde 20142019 yılları arasında toplam 40 iş kazası meydana gelmiştir. Yıllara göre iş kazası sayıları incelendiğinde, 9 kaza ile 2019 yılı en fazla iş kazası olan yıldır, bunu 8 iş kazası ile 2016 yılı izlemektedir. Yıllara göre iş kazası sayıları farklılık göstermektedir ve sayının 5'in altına düşmediği tespit edilmiştir. İş yerinde meydana gelen kazaların ay yinelemesi incelendiğinde 6 yıl içerisinde toplam 40 iş kazasının oldu-
Tablo 6'da iş kazalarının mevsimlere göre dağılımı verilmiştir. Mevsimsel dağılımda işyerinde altı yılda yaşanan toplam 40 iş kazasının 17 si ilkbahar, 8'i kış mevsiminde yaşanmışırır. Ortalama ve Medyan (ortanca) iş kazası sayılar1 incelendiğinde ilkbahar mevsimi diğer mevsimlerden daha fazla iş kazası olan mevsimdir. Mart ve Nisan ayların-

Tablo 6: İşyerinde 2014-2019 Yılları Arasında Mevsimlere Göre İș Kazası Sayıları

\begin{tabular}{|c|c|c|c|c|c|}
\hline $\bar{\Sigma}$ & 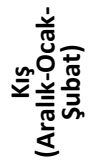 & 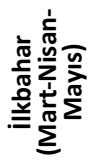 & 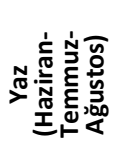 & 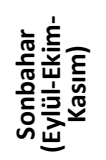 & $\frac{\frac{\varepsilon}{\pi}}{\frac{0}{0}}$ \\
\hline 2019 & 2 & 4 & 2 & 1 & 9 \\
\hline 2018 & 3 & 1 & - & 1 & 6 \\
\hline 2017 & 1 & 3 & 1 & - & 5 \\
\hline 2016 & 1 & 4 & - & 1 & 8 \\
\hline 2015 & 1 & 3 & 1 & - & 5 \\
\hline 2014 & - & 2 & 3 & 2 & 7 \\
\hline Toplam & 8 & 17 & 7 & 5 & 40 \\
\hline Ort $\pm s s$ & $1,3 \pm 1,0$ & $2,8 \pm 1,1$ & $1,2 \pm 1,1$ & $0,8 \pm 0,7$ & $6,6 \pm 1,6$ \\
\hline Median & 1,0 & 3,0 & 1,0 & 1,0 & 6,5 \\
\hline
\end{tabular}


Tablo 7: İşyerinde 2014-2019 Yılları Arasında Soğuk ve Ilık/Sıcak Geçen Aylara Göre İș Kazası Sayıları

\begin{tabular}{cccc}
\hline Yıllar & $\begin{array}{c}\text { Soğuk Geçen } \\
\text { Aylar } \\
\text { (Kasım-Nisan } \\
\text { arası) }\end{array}$ & $\begin{array}{c}\text { Ilık ve Sıcak } \\
\text { Geçen Aylar } \\
\text { (Mayıs-Ekim } \\
\text { arası) }\end{array}$ & TOPLAM \\
\hline 2019 & 6 & 3 & 9 \\
2018 & 4 & 2 & 6 \\
2017 & 3 & 2 & 5 \\
2016 & 5 & 3 & 8 \\
2015 & 4 & 1 & 5 \\
2014 & 2 & 5 & 7 \\
\hline TOPLAM & 24 & 16 & 40 \\
\hline Iş kazası & $4,0 \pm 1,4$ & $2,6 \pm 1,3$ & $6,6 \pm 1,6$ \\
ort \pm ss & 4,0 & 2,5 & 6,5 \\
\hline Median & & & \\
\hline
\end{tabular}

da batı Anadolu'da bahar mevsimi özellikleri görülürken Erzurum ilinde kış mevsiminin halen hissedildiği, kar yağışlarının görüldüğü ve ortalama sıcaklıkların $-11,8{ }^{\circ} \mathrm{C}$ ve $+4,1^{\circ} \mathrm{C}$ arasında değiştiği bilinmektedir.

Grafik 1: İşyerinde Yıllara ve Mevsimlere Göre İş Kazası Sayıları

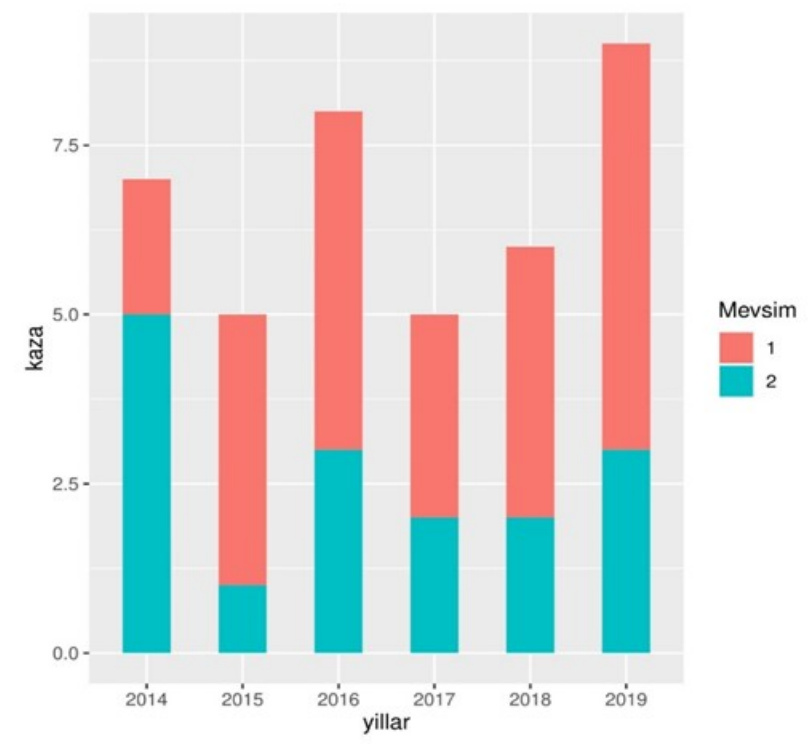

Mevsim1: Soğuk Geçen Aylar,

Mevsim2: Ilık ve Sıcak Geçen Aylar.

Bu bağlamda coğrafik dört mevsim yerine Erzurum için ikili bir sınıflama yapılarak soğuk geçen aylar (KasımAralık-Ocak-Şubat-Mart-Nisan), ılık ve sıcak geçen aylar (Mayıs-Haziran-Temmuz-Ağustos-Eylül-Ekim) olarak tekrar gruplama yapılmıştır. Tablo 7’de soğuk ve 1 lık/sıcak geçen aylara göre iş kazası sayılarının dağılımı verilmiş olup bu dağılımın grafiği de aşağıda sunulmuştur (Grafik 1).

İşyerinde altı yıl içinde gerçekleşen toplam iş kazasından 24'ü Kasım-Nisan ayları arasında soğuk geçen aylarda yaşanmıştır. Ortalama ve Medyan iş kazası sayıları da 1 lık/ sıcak geçen aylara göre yaklaşık bir buçuk kat fazladır.

\section{TARTIŞMA VE SONUÇ}

İş kazası ve yaralanmaları çalışma yaşamının en önemli sorun alanlarından biridir. Son yıllarda iş güvenliği alan yazınında üzerinde önemle durulan güvenlik kültürü oluşturulmasının yanında, bulunulan bölgeye ve yöreye özgü çevresel faktörlere ilişkin önlemler alınması da iş kazalarının önlenmesi konusunda gereklidir[15]. Aşırı soğuk ve aşırı sıcak hava koşullarında çalışmanın fiziksel sorunlar yanında psikolojik sıkıntılara da yol açtığı bilinmektedir [16]. Kişi nedenli olmayan iş kazalarının nedenleri arasında çevre, makine, malzeme kaynaklı, ortam elverişsizlik ve düzensizliği, yetersiz aydınlatma, gürültü olduğu gibi sıcaklık koşulları da önemli bir yere sahiptir[17]. Avustralya'da yapılmış olan bir çalışmada yüksek sıcaklıktaki günlerde iş kazası riskinin en üst düzeyde olduğu belirlenmiştir[18]. Ayrıca bölgelerin coğrafi konum ve mevsim özelliklerinin direkt ya da dolaylı olarak iş kazası sebebi olabileceği ifade edilmiştir. Hava sıcaklıklarının bireyler üzerinde konfor ve performanslarına etkisi konusunda yapılan bir çalışmada ise hafifçe serin $\left(22^{\circ} \mathrm{C}\right)$ sıcaklıkların optimum performans için gerekli olduğu, öğrenmenin büyük ölçüde sıcaklıktan etkilendiği belirlenmiştir[19]. Avrupa genelinde soğuğa bağlı ölümlerin görülmesinde önemli halk sağlığı sorunları olarak; uzun süre soğuk hava maruziyeti ve neden olduğu hastalıklar ile bu durumlarda iş kazaları risklerinin artması ifade edilmiştir[20]. Amerika'da yapılan bir çalışmaya göre, bölgesel farklılıklar, hassas popülasyona sahip merkez- 
ler ve iklim koşullarının ölümle ilişkili olduğu, ölüm riskinin de soğuk havalarda arttığı belirlenmiştir[21]. Ayrıca Amerikan İş Sağlığı Güvenliği Enstitüsü'nü yayınladığı raporda (2019) soğuk iklim şartlarının iş yerlerinde hastalık ve yaralanmalara neden olabileceği bu konuda önlemlerin alınması gerekliliği vurgulanmışırı [22]

İş sağlığı ve güvenliği kapsamında hava koşulları ve sıcaklık başlığı altında incelenmesi gereken en önemli faktör; yüksek ve düşük sıcaklıklarda görülmesi mümkün olan Isı stresidir. İklim şartlarından kaynaklanan ısı stresi, çalışanların performansı ve iş kazaları üzerinde etkilidir. Bununla birlikte gıda sanayi, yol bakım, elektrik, bakım ve onarım sektörleri soğuk stresi açısından riskli sektörlerdir [23]. Soğuk iklim koşullarında çalışan personellerin ısı kaybını önlemek amacıyla uygun koruyucu donanımlarını kullanmaları gerekmektedir. Bu konuda Päivinen'in (2006) yaptığı çalışmada, tehlikeli işlerde çalışanlar için iş kazalarında soğuk havanın önemli bir faktör olduğu ve buzlanma olaylarına karşı da önlem alınması gerekliliği vurgulanmıştır[24]. Dovrat ve Katz-Leurer (2007) ise, soğuk havalarda çalışan işçilerin yoğunlukla bel ağrılarından yakındığı ve bu durumunda iş ortamında iş kazaları açısından risk oluşturduğu ayrıca iş gücü kayıplarına neden olduğundan bahsetmişlerdir[25]. ABD Çalışma İstatistikleri Bürosunun yayınladığı rapora göre, 2017 yılında 20 binin üzerinde sulu kar, kar ve buzla ilişkili iş kazalarının görüldüğü ve bunların \%14’ünün (2890 olgu) New York eyaletinde olduğu ifade edilmiştir [26]. Alaska eyaletinde yapılan bir çalısmada (2014) ise, soğuk iklim şartlarında çalışanların ventriküler fibrilasyon gibi kalp rahatsılıkları ve uzun vadede nörolojik hastalıklara yatkınlıklarının da arttığı bu rahatsızlıkların iş kazalarının oluşumunda önemli etkenler olduğu belirtilmiştir[27].

SGK verileri değerlendirildiğinde; Erzurum şehrinin 2010 yılından itibaren en çok iş kazası görülen iller istatis- tiklerine girmediği görülmektedir[28]. Bu sevindirici bir sonuç olmasına rağmen soğuk hava koşullarının hâkim olduğu bu şehirde, iklimin iş kazaları ve yaralanmalarına etkisinin incelenmesi uygun görülmüştür. İşyerinde az sayıda iş kazası olması nedeniyle yapılan analizlerde istatistiksel anlamlı bir ilişki tespit edilmemiştir. Bununla birlikte Erzurum ilinde soğuk havanın Ekim ayında başlayarak Nisan ayına kadar yoğunlukla hissedildiği göz önüne alındığında bu dağılım soğuk iklimin iş kazalarına etkisi olduğu yönünde bir bulgu olarak kabul edilebilir. Soğuk hava koşullarının hâkim olduğu Erzurum ilinde tüm işkollarını içerecek şekilde serinin genişletilmesi ile iklimin iş kazası ve yaralanmalarına etkisinin ayrıntılı incelenmesinin iş sağlığı ve güvenliği uygulamalarına katkı sağlayacağı sonucuna varılmışıtır. Bu çalışmadan hareketle soğuk iklimde oluşabilecek riskler göz önüne alınarak her işyerinde bu duruma ilişkin kaza senaryolarının hazırlanması ve bu senaryolara yönelik kontrol tedbirlerinin geliştirilmesi önerilmektedir. İster kapalı ister açık alanda her sektörde soğuğa maruziyetle çalışanların bu duruma bağlı kaza ve yaralanmalara karşı risk etmenleri konusunda bilgilendirilmeleri, iş ve sıcaklık koşullarına özgü kişisel koruyucu donanımlarını kullanarak çalışmaları, herhangi bir tehlike durumunda ise ilk yardım uygulamaları konusunda eğitimli olmaları önerilmektedir. Bu fabrikaya ve Erzurum’a özgü olarak da iş kazalarının kök neden analizlerinde iklim koşullarının göz önünde bulundurulması bir diğer öneri olarak sunulmaktadır. İl çalışma istatistikleri ise bu bağlamda analiz edilmelidir. Ayrıca soğuk ve sıcak iklimin iş kazalarına etkilerinin ayrıntılı olarak tüm çalışma alanlarında irdelenmesinin iş güvenliği kültürünün oluşmasına ve işs sağlığı ve güvenliği uygulamalarına olumlu etki edeceği değerlendirilmektedir.

YAZAR KATKILARI: Bu çalışmada yazarların katkıları eşit düzeydedir.

ÇıIKAR ÇATIşMası: Bu çalışmada herhangi bir çıkar çatış- 
ması yoktur, makale araştırma ve yayın etiğince uygundur.

Finansal Destek: Bu çalışmada herhangi bir kişi, kurum veya kuruluştan finansal destek alınmamıştır.

Етік Коміте Onayı: İnsan örneği veya deneysel çalışma içermediğinden etik kurulu oluru gerekmemiştir.

\section{KAYNAKÇA}

[1] Karadeniz O. (2012). Dünya'da ve Türkiye'de İş Kazaları ve Meslek Hastalıkları ve Sosyal Koruma Yetersizliği. Çalışma ve Toplum Dergisi, (3), 34.

[2] TMMOB Makina Mühendisleri Odası İşçi Sağlığı ve İş Güvenliği Raporu. 2018. Ankara. Makina Mühendisleri Odası.

[3] ILO. (2017), Erişim Tarihi: 19.11.2019, http:// www.ilo.org/global/topics/safety-and-health-at-work/ lang-en/index.htm.

[4] SGK. (2019). Erişim Tarihi: 18.11.2019. http:// www.sgk.gov.tr/wps/portal/sgk/tr/kurumsal/istatistik/ sgk_istatistik_yilliklari.

[5] TUSIAG. (2017). Erişim Tarihi: 20.09.2019, https://tuisag.com/2017-yili-is-kazasi-meslekhastaliklari-istatistikleri.

[6] Bilim A, Çelik O N. (2018). Türkiye'deki İnşaat Sektöründe Meydana Gelen İş Kazalarının Genel Değerlendirmesi. Ömer Halisdemir Üniversitesi Mühendislik Bilimleri Dergisi, 7(2): 725-731.

[7] Dağlı B, Serinken M. (2012). Occupational Injuries Admitted to the Emergency Department. The Journal Of Academic Emergency Medicine. JAEM, 11: 167-70.

[8] Marino C, de’Donato F, Michelozzi P, D’Ippoliti D,Katsouyanni K, Analitis A, Biggeri A, Baccini M, Accetta G, Perucci CA. (2009). The PHEWE Collaborative Group. Effects of cold weather on hospital admissions. Results from 12 European cities within the PHEWE Project. Epidemiology; 20(6): 67-8. DOI: 10.1097/01.ede.0000362910. 23459.81.

[9] Güllüoğlu E N, Taçgın E. (2018). Türkiye Tekstil Sektöründe İstihdam ve İş Kazalarının Analizi. Journal of Textiles and Engineer, 25(112): 344-354.

[10] Jackson L. (2001). Non-fatal occupational injuries and illnesses treated in hospital emergency departments in the United States. Injury Prevention, 7 (Suppl I): i21-26.

[11] Ricco M. Air Temperature Exposure And Agricultu- ral Occupational Injuries In The Autonomous Province Of Trento (2000-2013, North-Eastern Italy). International Journal of Occupational Medicine and Environmental Health. 2018;31(3):317 - 331.

[12] Bonafede M, Marinaccio A, Asta F, Schifano P, Michelozzi P and Vecchi S. (2016). The association between extreme weather conditions and workrelated injuries and diseases. A systematic review of epidemiological studies. Ann Ist Super Sanità, Vol. 52, No. 3: 357-367.

[13] Karaca A, Şenol A, Denizli F, Çiçek M, Derman Y. Kentlerde Hava Kalitesinin Geliştirilmesi ProjesiKentair. Erzurum Hava Kalitesi Değerlendirme Raporu. Erzurum. 2013.

[14] MGM. (2019). Erişim Tarihi:19.11.2019. https:// www.mgm.gov.tr/veridegerlendirme/il-ve-ilceleristatistik. aspx=ERZURUM.

[15] Camkurt M Z. (2007). İşyeri Çalışma Sistemi ve İşyeri Fiziksel Faktörlerinin İş Kazaları Üzerindeki Etkisi. TÜHİS İş Hukuku ve İktisat Dergisi, 20 (6): 1 .

[16] Makinen TM, Hassi J. (2009). Health Problems in Cold Work. Ind Health, 47(3):207-20.

[17] Khanzode, V. V., Maiti, J., ve Ray, P., (2012), "Occupational injury and accident research: A comprehensive review”, Safety Science, S. 50, s. 13551367.

[18] Varghese BM, Hansen A, Bi P, Pisaniello D. (2018). Are workers at risk of occupational injuries due to heat exposure? A comprehensive literature review, $110: 380-392$.

[19] Cui W, Cao G, Park H J, Ouyang Q, Zhu Y. (2013). Influence Of Indoor Air Temperature On Human Thermal Comfort, Motivation And Performance, 68:114-122.

[20] Analitis A, Katsouyanni K, Biggeri A, Baccini M, Forsberg B, Bisanti L, Kirchmayer U, Ballester F, Cadum E, Goodman P G, Hojs A, Sunyer J, Tiittanen P and Michelozzi P. (2008). Effects of Cold Weather on Mortality: Results From 15 European Cities Within the PHEWE Project.American Journal of Epidemiology, 168:1397-1408.

[21] Anderson BG, Bell ML. (2009). Weather-related mortality. How heat, cold, and heat waves affect mortality in the United States. Epidemiology, 20 (2):205-13. DOI: 10.1097/ EDE.0b013e318190ee08.

[22] NIOSH [2019]. Preventing cold-related illness, injury, and death among workers. Jacklitsch B, Cebal- 
los D. Cincinnati, OH: U.S. Department of Health and Human Services, Centers for Disease Control and Prevention, National Institute for Occupational Safety and Health. DHHS (NIOSH), 2019-113. https://doi.org/10.26616/

NIOSHPUB2019113external icon

[23] Ontario Ministry of Labour Healty and Safety, Heat Stress Guide, June 2014, Canada.

[24] Päivinen, M. Electricians' perception of work-related risks in cold climate when working on high places. (2006). International Journal of Industrial Ergonomics, 36, 661-670. doi: 10.1016/ j.ergon.2006.04.005.

[25] Dovrat E, \& Katz-Leurer M. (2007). Cold exposure and low back pain in store workers in Israel. American Journal of Industrial Medicine, 50, 626-631. doi:10.1002/ajim.20488.

[26] U.S. Bureau of Labor Statistics (2020). https:// ohsonline.com/articles/2020/02/11/cold-and-winterweatherrelated-workplace-injuries-and-tips-toprevent-them.aspx.

[27] State of Alaska DHSS [2014]. Cold injuries guidelines. Juneau, AK: Department of Health and Social Services, Division of Public Health, Section of Emergency Programs, Emergency Medical Services (EMS) Program http://dhss.alaska.gov/dph/Emergency/ Documents/ems/documents/Alaska\%20.DHSS\% 20EMS\%20Cold\%20Injuries\%20Guidelines\%20 June\%202014.pdf

[28] SGK. 2018. SGK İstatistik Yıllıkları. Erişim Tarihi: 19.11.2019. http://www.sgk.gov.tr/wps/portal/sgk/ tr/kurumsal/istatistik/sgk_istatistik_yilliklari. 